\title{
Performance of Wastewater Treatment Plants in Iraq: Life Cycle Assessment Approach
}

\author{
Isam Alyaseri ${ }^{1}$ \\ I'Isam Alyaseri, Ph.D., Assistant Professor, Department of Civil Engineering, Al-Muthanna University, Al- \\ Samawah 72001, Iraq, and Visiting Assistant Professor, Department of Civil Engineering, Southern Illinois \\ University Edwardsville, Edwardsville, IL 62026-180)
}

\begin{abstract}
Natural water system in Iraq is facing massive destruction and quality degradation mainly due to absence of an effective protection regulations against direct discharge of pollutants, and inefficient wastewater treatment at Iraq's sewage treatment plants. Alsamawah City is the center of Almuthanna Province in Southern Iraq. The wastewater treatment plant that serves the city is facing major problems related to improper design and/or implementation of structural plan, lack of professional operators, power shortage, and lack of maintenance. An environmental evaluation of the plant was conducted. The plant was not able to reduce the tested contaminants properly, and failed to comply with standards. Effluent average concentration of oil and grease, TSS, CL-, NH3, COD, and H2S was 42.0, 5.4, 3.5, 1.6, 1.2, and 1.2 times higher than the local standards, respectively. It complies only at the events when a contaminant is originally had low concentration in the raw sewage. In most sampling events the results show that wastewater was leaving plant with little to no treatment, turning the plant into the top point source polluter in the province. To quantify and show decision makers the damages occurred due to improper treatment at the plant, life cycle assessment methodology (endpoint approach) was used. Annual damages from Alsamawah WWTP are $7.3( \pm 0.8)$ years loss in human life, $2.5 \times 10-2( \pm 2.9 \times 10-3)$ species loss in the area, and $\$ 1.1 \times 10+7( \pm 1.2 \times 10+6)$ more expenses needed for future generations for resources.
\end{abstract}

Keywords: wastewater treatment, life cycle assessment, developing countries, Iraq

\subsection{Wastewater Treatment in Iraq}

\section{Introduction}

The purpose of wastewater treatment is to remove or reduce contaminants in water that impose threats to human and environment if discharged to surface and/or ground waters without proper treatment. While developed countries are continuing working on setting more efficient treatment processes in the WWTPs or establishing new technologies to meet the increasing demand for water, the developing countries are still straggling to establish the required infrastructure for treatment. Although the damage from lack of such infrastructure is obvious, the public concern still limited due to lack of governmental programs that explain the environmental problems for public and the influence of crisis and political conflicts in these countries. Current outreach programs in these countries are still limited and not operative. Increases in water pollution, concomitant with water scarcity may limit economic development and lead to the commonness of poverty, hunger and disease.

Problem of improper wastewater treatment is acute in countries suffering crisis like Iraq. Decades of wars and sanctions in Iraq combined with limited environmental awareness in both public and governmental representatives, have highly contributed to the destruction of Iraq's national water system. According to the United Nations report [1], six million people have no access to clean water and more than 500,000 Iraqi children access their water from a river or creek and that over 200,000 access their water from an open wells. In the first six months of 2010, there were over 360,000 diarrhea cases as a result of polluted drinking water and a lack of hygiene awareness among local communities, particularly vulnerable groups such as women and children. The report showed that "Every day at least 250,000 tonnes of raw sewage is pumped into the Tigris river threatening unprotected water sources and the entire water distribution system" [1].

Currently, the lack of permanent governmental programs for environment protection, lack of expenses, unavailability of professionals, engineers, and skilled operators, unprofessional design and treatment of most of existing plants, and lack of public awareness about the danger of direct discharge of wastewater to water courses had led to serious deficiencies in operations in the country's wastewater treatment plants. Most of these plants were not designed based on a proper local data and were constructed by inexperienced companies. In addition to the improper design and implementation, the mechanical and electrical equipment at these plants have suffered from lack of spare parts and no preventative maintenance due to lack of expenses and trained operators. In many cases untreated raw sewage is directly discharged into Rivers, endangering the health of residents and downstream populations. 
Many studies performed to evaluate the wastewater treatment in Iraq [2, 3, 4, 5]. Al-Rawi and Altayar, evaluated the wastewater treatment operations of a plant in the City of Al-Mosul. They concluded that the absence of an experienced operators and the lack of dissolved oxygen are the main reason for the deficiency in treating organic contents [6]. Alsaqqar et al., evaluated the performance of a WWTP in Al-Diwaniya, one of the cities in the southern Iraq. The study indicated many operational problems that render the level of $\mathrm{BOD}_{5}, \mathrm{COD}$, TSS and $\mathrm{NO}_{3}$ exceeded the disposal limitations [7].

\subsection{Wastewater Treatment Evaluation Using Life Cycle Assessment Methodology}

Roeleveld et al., showed that the minimization of pollutants discharge and sludge production is more important than minimization of energy consumption when the sustainability of the WWTP has to be improved [8]. If the processes in the wastewater treatment plant (WWTP) did not reduce pollutants properly, damages would be occurred on receiving water and human health. Assessment of damages or impacts can be achieved through the use of life cycle assessment (LCA) methodology [9]. ISO 14044 defined LCA as a method for assessing the environmental impacts associated with a product or a process [10]. LCA methodology becomes more and more common in recent years [11].

Although the use of LCA on wastewater management was covered by many studies during the last few years $[12,13,14,15,16,17]$, there is still a need for more studies due to variation in spatial and temporal conditions on each case study, along with the difference in environmental concerns from one place to another. In developing countries, such studies can help evaluating the damages due to improper treatment. They also can help environment protection activists to rise the public awareness about the wastewater contamination.

\subsection{Goal and Scope of the Study}

Objective of this study is to enlighten public and decision makers about the damages occured due to wicked planning and operations on wastewater treatment plants using one example in the City of Alsamawah southern Iraq. The study aim to evaluate the environmental performance of the existing wastewater treatment train in the plant using the life cycle assessment methodology.

\subsection{Life Cycle Impact Assessment Method}

\section{Materials And Methods}

To describe the impacts, LCA studies use a life cycle impact assessment (LCIA) method [18]. These methods are based on two approaches; the midpoint and the endpoint. The midpoint approach uses the categories that lay in the middle of the cause-effect chain. Examples of these midpoint categories are global warming that is measured in $\mathrm{kg} \mathrm{CO}_{2}$ eq., acidification measured in $\mathrm{H}^{+}$moles eq., and ozone layer depletion measured in kg CFC-11 eq., while the endpoint approach is changing the midpoint impact categories to more specific damage categories on human, ecosystem, and resources. Damages on human are calculated based on the equivalent cancer cases. Damages on ecosystem are evaluated by estimating the fraction of species affected by the nutrients and toxics introduced to environment, and the damages on resources are evaluated based on the calculation of surplus energy or expenses needed by future generation to extract the resources they need due to the current use of resources by our generation.

Changing a unit of substance released from a process or product into equivalent cancer cases in human, disappearance for some species in environment, or surplus expenses needed by future generation, on the endpoint level, needs to facilitate more structured and informed weighting process than the midpoint level. Besides the transparency difficulty, data availability represents one of the biggest constraints that are limiting the use of endpoint approach but, with the increasing interest in LCA methodology and increasing in the number of epidemiological and environmental studies [19], the link between the inventory and potential end damages on human, ecosystem, and resources for most categories becomes available [20].

Although the midpoint approach is easier to perform (less data and assumptions required), it has complications in understanding impacts. It is hard for the public to understand the impacts cause by one kilogram of $\mathrm{NO}_{\mathrm{x}}$ emitted to air in a highly populated area, or the impacts of one kilogram of $\mathrm{PO}_{4}$ emitted to a lake. Endpoint approach gives public, decision makers, and regulatory agencies easier understanding for the final damages [21]. Also, it is more useful for the environmental activists to use results from endpoint approach to explain their concerns to the society especially where and when the public understanding about the environmental problem is limited.

\subsection{The Selection of Life Cycle Impact Assessment Method}

Examples of methods using endpoint approach now are Eco-indicator 99, IMPACT 2002, and ReCiPe 2008 [22, 23, 24, 20]. ReCiPe 2008 method is a newer version of Eco-indicator 99. It converts the life cycle inventory (LCI) into disability years in human, a percentage of decreased biodiversity over an area during a 
certain period in environment, or energy needed by future generations due to the depletion in resources. The method also estimates the overall impacts in a single score (point, Pt or millipoint, $\mathrm{mPt}$ ).

ReCiPe 2008 contains two sets of impact categories with related sets of characterization factors. At the midpoint level, the impact categories are: climate change (CC), ozone depletion (OD), terrestrial acidification (TA), freshwater eutrophication (FE), marine eutrophication (ME), human toxicity (HT), photochemical oxidant formation (POF), particulate matter formation (PMF), terrestrial ecotoxicity (TET), freshwater ecotoxicity (FET), marine ecotoxicity (MET), ionizing radiation (IR), agricultural land occupation (ALO), urban land occupation (ULO), natural land transformation (NLT), water depletion (WD), mineral resource depletion (MRD), and fossil fuel depletion (FD). These midpoint impact categories are further converted and aggregated into three endpoint categories: damage to human health $(\mathrm{HH})$, damage to ecosystem diversity (ED), and damage to resource availability (RA). The ReCiPe method used in this study was based on a Hierarchist perspective. World characterization and normalization factors in ReCipe were used on which enable the method to be used outside Europe. There are no local normalization factors available for the country of study area.

\subsection{System Boundaries}

LCA influenced by the selection of system boundaries [25]. Parameters or phases with small contributions are avoided when possible [26, 27, 28]. The boundaries of the system start at the point where the wastewater is entering the sewer system. The functional unit was defined as one cubic meter of raw wastewater. The system boundaries include the phases of construction and operations. Construction materials include production, manufacturing and end of life phases. Electricity used for operations were included. Minor consumable materials (such as offices supplies, monitoring devices, etc.) and labor were not included in this study. Since no sludge was transported yet from the plant, the transportation of end product (sludge) to the point of end disposal was not included. Land occupied by processes was included. No chemicals are used to enhance settling. Maintenance was not included due to the lack of maintenance.

\subsection{Inventory Analysis}

A life cycle inventory (LCI) was performed by collecting inventory data from the case study (AlSamawah WWTP). The consumption of electricity was obtained from plant records $\left(0.142 \mathrm{kWh} / \mathrm{m}^{3}\right.$ of raw sewage). This consumption is less than $0.279 \mathrm{kwh} / \mathrm{m}^{3}$ (10 kBtu/gallon/day) which is the median reported by [29] for energy use in the wastewater treatment plants. The plant facing many problem such as the power shortage. The average supply of power to the plant is only 16 to 20 hours a day from national grid. Emissions to river of biochemical oxygen demand $\left(\mathrm{BOD}_{5}\right)$, chemical oxygen demand (COD), total suspended solids (TSS), phosphates $\left(\mathrm{PO}_{4}\right)$, Nitrates $\left(\mathrm{NO}_{3}\right)$, ammonia $\left(\mathrm{NH}_{3}\right)$, chlorides $(\mathrm{CL})$, oil and grease $(\mathrm{O} \& \mathrm{G})$, and hydrogen sulfide $\left(\mathrm{H}_{2} \mathrm{~S}\right)$ where taken from the laboratory analysis in the plant. Other emissions to air and water were taken from Ecoinvent database. Sewer and WWTP infrastructure burdens were adopted from Ecoinvent database as well. No chemicals or natural gas are used in the plant.

\subsection{Case Study Description: Al-Samawah Wastewater Treatment Plant}

Al-Samawah WWTP was designed to treat $37000 \mathrm{~m}^{3} /$ day. It receives wastewater from residential, commercial, and industrial areas in Al-Samawa City southern Iraq. The actual estimated flow rate is 5.2 MGD $\left(20000 \mathrm{~m}^{3} /\right.$ day). The plant consists of grit removal and secondary treatment processes. The preliminary stage consists of a bar rack screen and two grit chambers for grit removal. The grit chambers were not designed properly as the wastewater are not confined for enough retention time to allow grit settling. From grit chambers, the wastewater is moved to an aeration basins. For unknown reason, no primary treatment exist in the plant. The secondary treatment process is an activated sludge process consist of four aeration basins and four secondary clarifiers. Floated surface aerators (propeller type) are used to provide air to aeration tanks.

Prior to discharge to Al-Samawah River, effluent from the secondary clarifiers flows into a chlorine chamber for disinfection. For unknown reason, no de-chlorination unit was designed for the plant. Wasted sludge is taken from the secondary clarifiers and is pumped into two gravity thickeners where the supernatant is pumped back to the distribution chamber and the settled sludge is pumped to the drying beds. The construction works in the plant was done by 2012. Since that time, the plant was facing major problems in complying with the discharging standards. Bar screens are not maintained properly and solids are filling the grit chambers, aeration tanks, and the secondary clarifiers. Solids drying beds were not filled since 2012.

\section{Results And Discussion}

\subsection{Data Analysis}

Table 1 shows the data of 11 contaminants obtained from plant's laboratory from October 2012 to January 2015. The average suspended solids concentrations in the discharged wastewater was $325 \mathrm{mg} / \mathrm{L}$. Among 89 sampling events, only one was below the $30 \mathrm{mg} / \mathrm{L}$ standard. The average reduction in suspended 
solids was limited to $10 \%$ indicating high deficiency in the plant's processes. The deficiency is mainly related to inefficient grit removal, lack of primary treatment, and bypassing of wastewater directly to the aeration tanks during the time when screw pumps are malfunctioning. Recently, solids entering the plant are either discharged to the river or accumulated in plant's basins. Consequently, grits and suspended solids are accumulated in the aeration tanks and secondary clarifiers, clogging some piping, and creating some anaerobic conditions.

Table 1. Influent and Effluent Concentrations for Ten Contaminants Measured in Al-Samawah- WWTP Lab.

\begin{tabular}{|c|c|c|c|c|c|c|}
\hline Parameter, mg/L & Date & \# of Tests & Range & Average & St. Deviation & Iraq's Standards \\
\hline \multirow[t]{2}{*}{ BOD $_{5}$} & Influent & 69 & $10-230$ & 103.9 & 45.9 & \\
\hline & Effluent & 64 & $5-105$ & 35.8 & 18.5 & 40 \\
\hline \multirow[t]{2}{*}{ COD } & Influent & 81 & $20-380$ & 217.4 & 65.6 & \\
\hline & Effluent & 80 & $12-188$ & 117.6 & 32.5 & 100 \\
\hline \multirow[t]{2}{*}{ TSS } & Influent & 79 & $20-2040$ & 455.2 & 274.9 & \\
\hline & Effluent & 89 & $20-540$ & 324.5 & 113.6 & $30-60$ \\
\hline \multirow[t]{2}{*}{ TDS } & Influent & 71 & $1240-9020$ & 5701 & 1869 & \\
\hline & Effluent & 79 & $1280-7800$ & 5717 & 1515 & - \\
\hline \multirow[t]{2}{*}{$\mathrm{SO}_{4}$} & Influent & 76 & $57-3884$ & 1267 & 566 & \\
\hline & Effluent & 76 & $92-3872$ & 1355 & 526 & - \\
\hline \multirow[t]{2}{*}{$\mathrm{PO}_{4}{ }^{-3}$} & Influent & 85 & $0.02-1.07$ & 0.3 & 0.2 & \\
\hline & Effluent & 83 & $0.01-0.30$ & 0.1 & 0.1 & 3.0 \\
\hline \multirow[t]{2}{*}{$\mathrm{NO}_{3}$} & Influent & 69 & $3-50$ & 13.3 & 9.2 & \\
\hline & Effluent & 70 & $1-46$ & 11.7 & 10.4 & 50 \\
\hline \multirow[t]{2}{*}{$\mathrm{CL}^{-}$} & Influent & 89 & $222-3937$ & 2104 & 857 & \\
\hline & Effluent & 89 & $222-3365$ & 2086 & 738 & 600 \\
\hline \multirow[t]{2}{*}{$\mathrm{NH}_{3}$} & Influent & 58 & $0.5-32.8$ & 15.3 & 7.0 & \\
\hline & Effluent & 53 & $0.7-43.6$ & 16.2 & 7.9 & 10.0 \\
\hline \multirow[t]{2}{*}{ O\&G } & Influent & 42 & $38-560$ & 220 & 165 & \\
\hline & Effluent & 38 & $18-480$ & 168 & 144 & 4.0 \\
\hline \multirow[t]{2}{*}{$\mathrm{H}_{2} \mathrm{~S}$} & Influent & 70 & $3.4-51.0$ & 23.1 & 11.1 & \\
\hline & Effluent & 28 & $0.4-10.6$ & 3.8 & 2.6 & 3.0 \\
\hline
\end{tabular}

Among 64 sampling events for the effluent $\mathrm{BOD}_{5}$ concentration, 16 samples $(25 \%)$ exceeded the 40 $\mathrm{mg} / \mathrm{L}$ level. The plant was able to reduce the concentration of $\mathrm{BOD}_{5}$ from $103.9 \mathrm{mg} / \mathrm{L}$ in the raw wastewater to $35.8 \mathrm{mg} / \mathrm{L}$ in the discharged wastewater. Since the plant receiving around $50 \%$ of the designed flow rate, the reduction in $\mathrm{BOD}_{5}$ was achievable due to long retention time at the aeration tank. Most incompliance to the standards was occurred during the years 2013 through 2015 most likely due to accumulation of solids short period after the facility was started in 2012. Another reason is the insufficient aeration provided to wastewater in the aeration tank due to impairment in some mechanical aerators. No measurement of dissolved oxygen (DO) or specific oxygen uptake rate (SOUR) are available in the plant. Among 80 sampling events for the COD concentration in effluent, only eleven $(13.8 \%)$ were lower than the $100 \mathrm{mg} / \mathrm{L}$ standard. Among these eleven samples, six of them had initially low COD concertation in the raw wastewater.

For ammonia concentration, comparison between 54 influent vs. effluent samples, shows an average of zero reduction. In spite of lack of testing equipment, it is obvious that the lack of enough oxygen is responsible for the absence of nitrification process. Ammonia normally requires 3 to 4 times the aerobic capacity required for BOD removal. Despite the long retention time, aeration tanks provide low aeration due to power off problem and the frequent faulty of some of the mechanical aerators.

Table 1 shows that the average of TDS was $5717 \mathrm{mg} / \mathrm{L}$ ( $\mathrm{SD}=1515 \mathrm{mg} / \mathrm{L}$ ). This high concentration of TDS can cause extreme damage to the aquatic life and to the source of drinking water in the area. Although, wastewater treatment plants have no limits for discharging their effluent with high TDS to streams, this case study indicate the need for such limits to protect aquatic life and drinking water sources. One approach for setting limits for TDS may base on the water quality suitable for drinking. American standard for TDS in drinking water is limited to $500 \mathrm{mg} / \mathrm{L}$, while the WHO standard is $1000 \mathrm{mg} / \mathrm{L}$. For example in 2010 , The Environmental Quality Board in the State of Pennsylvania in the U.S. set a new wastewater treatment requirements for TDS. The goal of the regulation was to ensure that the concentration of TDS in Pennsylvania's streams does not exceed the water quality criterion of $500 \mathrm{mg} / \mathrm{L}$ [30]. Data from office of environment protection in the City of Al-Samawah indicated that Al-Samawah River already exceeded these levels. The average concentration of TDS in the river for August and September, 2015 was $3050 \mathrm{mg} / \mathrm{L}$ representing 300\% exceedance for WHO standards and $600 \%$ for American standards indicating serious environmental problem introduced to the river.

Table 1 shows that the average concentration of $\mathrm{H}_{2} \mathrm{~S}$ in the raw sewage was $23.1 \mathrm{mg} / \mathrm{L}$ indicating high septic condition and odor pollution. In addition to odor problems, this levels of $\mathrm{H}_{2} \mathrm{~S}$ in the sewer system may cause health risks to operators, and deteriorate the structural reliability of sewer system [31]. During the processes in the plant, the average concentration of $\mathrm{H}_{2} \mathrm{~S}$ are reduced to an average of $3.8 \mathrm{mg} / \mathrm{L}$ in the discharged 
wastewater. This average is higher than the taste and odor thresholds [32]. Iraq's standards for hydrogen sulfide is $3 \mathrm{mg} / \mathrm{L}$. Among 28 effluent samples tested in the plant, only 15 samples were below this standards.

The average concentration of sulfates was $1355 \mathrm{mg} / \mathrm{L}$ in the discharged wastewater and is shown in the table. Currently, no limits are imposed for sulfate level in the discharging wastewater to streams. As for drinking water, the level of sulfate is limited to $400 \mathrm{mg} / \mathrm{L}$ by Iraqi's standards and WHO, and $250 \mathrm{mg} / \mathrm{L}$ by American secondary standards. The average concentration of sulfate in the discharged wastewater did exceeded the two criterions. This may bring detrimental effects on downstream farmers whom using this water for multiple purposes (may include drinking and cattle feeding).

The table also shows that the chloride concentration was $2085 \mathrm{mg} / \mathrm{L}$ in the discharged wastewater. The range was $222 \mathrm{mg} / \mathrm{L}$ to $3365 \mathrm{mg} / \mathrm{L}$ and the lower bound of this range is very close to $230 \mathrm{mg} / \mathrm{L}$. $230 \mathrm{mg} / \mathrm{L}$ is the chronic water quality criteria for chloride set by USEPA [33]. The level of oil and grease may reach to as high as $480 \mathrm{mg} / \mathrm{L}$ as can be seen in the table. For 38 sampling events for oil and grease, none was comply with the local discharging limit (4 mg/L).

Most contaminants tested in the plant, does exceed the local maximum contamination limits for effluent, imposing high risk to human, animals, and aquatic life downstream. No action been made for correction so far.

\subsection{Life Cycle Analysis}

Using ReCipe method, the impacts and damages due to the processes were computed for the treatment of one cubic meter of raw sewage at Alsamawah WWTP. Four major groups of contributors to damage are shown in Fig. 1. The figure shows that damage on the human health is higher than the other damage categories (total of $29.5 \mathrm{mPt}$ ).

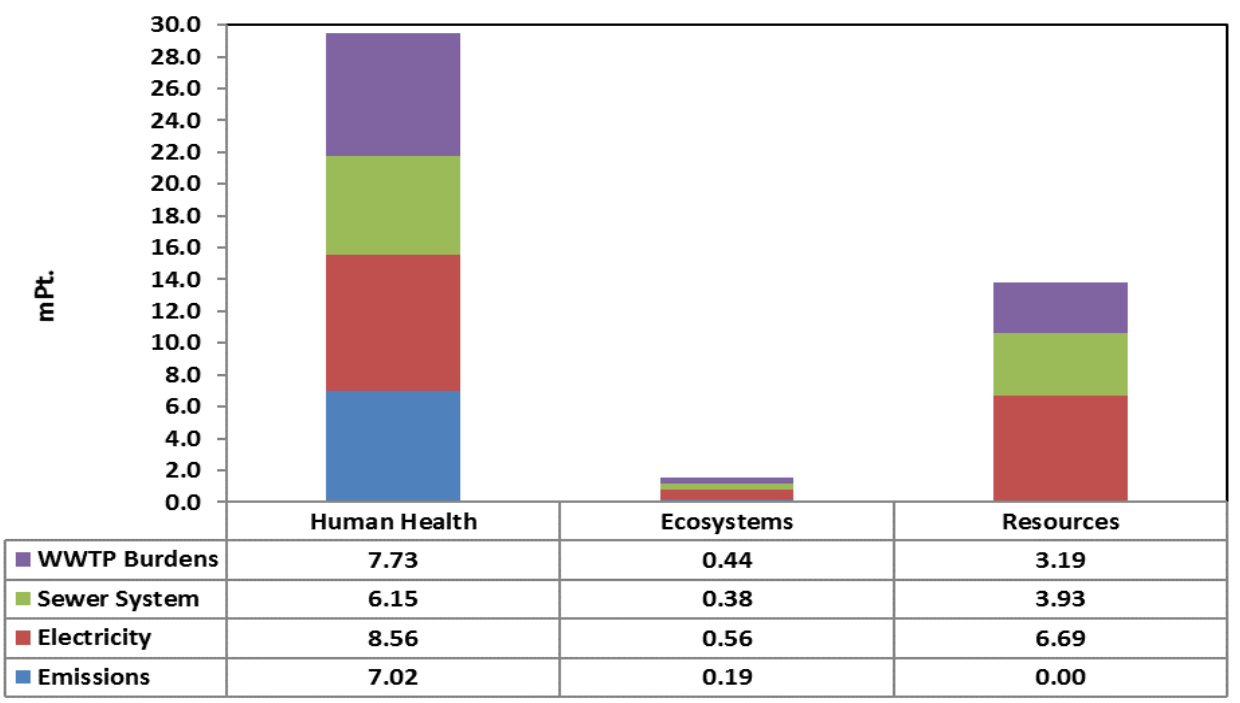

Fig 1 Weighted Damage Assessment Due to Treatment of One Cubic Meter of Raw Sewage at Alsamawah WWTP (Method: ReCiPe Endpoint (H) V1.05/World ReCiPe H/A/Weighting).

The Figure indicates that the impacts on human health are coming from electricity $(8.56 \mathrm{mPt})$, WWTP burdens $(7.73 \mathrm{mPt}$.), emissions to air and water $(7.02 \mathrm{mPt})$, and sewer system $(6.15 \mathrm{mPt})$. The damages to resources mainly comes from electricity $(6.69 \mathrm{mPt})$. Electricity also is the most significant contributor for the damage to the ecosystem. The results shows the need for an energy conservation and emission reduction in any correction or proposed alternative. Table 2 shows the damages on different categories due to treatment.

Table 2: Analysis of Existing Treatment in Alsamawah WWTP in the Impact Assessment, Damage Assessment, and Single Score Levels Using ReCipe Method (CI: 95\%).

\begin{tabular}{|l|l|l|}
\hline Impact Category & Unit & Damage \\
\hline Agricultural land occupation & Species.yr & $5.4 \times 10^{-11}\left( \pm 1.42 \times 10^{-11}\right)$ \\
\hline Climate change ecosystems & Species.yr & $3.06 \times 10^{-9}\left( \pm 3.84 \times 10^{-10}\right)$ \\
\hline Climate change human health & DALY & $5.40 \times 10^{-7}\left( \pm 6.79 \times 10^{-8}\right)$ \\
\hline Fossil depletion & $\$$ & $1.52( \pm 0.16)$ \\
\hline Freshwater eco-toxicity & Species.yr & $1.16 \times 10^{-12}\left( \pm 5.51 \times 10^{-13}\right)$ \\
\hline Freshwater eutrophication & Species.yr & $2.63 \times 10^{-11}\left( \pm 1.55 \times 10^{-11}\right)$ \\
\hline Human toxicity & DALY & $1.57 \times 10^{-7}\left( \pm 4.42 \times 10^{-8}\right)$ \\
\hline Ionizing radiation & DALY & $4.92 \times 10^{-10}\left( \pm 5.44 \times 10^{-10}\right)$ \\
\hline Marine eco-toxicity & Species.yr & $3.96 \times 10^{-15}\left( \pm 1.66 \times 10^{-15}\right)$ \\
\hline
\end{tabular}




\begin{tabular}{|l|l|l|}
\hline Metal depletion & $\$$ & $6.21 \times 10^{-3}\left( \pm 2.01 \times 10^{-3}\right)$ \\
\hline Natural land transformation & Species.yr & $9.44 \times 10^{-11}\left( \pm 3.00 \times 10^{-11}\right)$ \\
\hline Ozone depletion & DALY & $6.84 \times 10^{-11}\left( \pm 8.95 \times 10^{-12}\right)$ \\
\hline Particulate matter formation & DALY & $2.98 \times 10^{-7}\left( \pm 3.08 \times 10^{-8}\right)$ \\
\hline Photochemical oxidant formation & DALY & $7.15 \times 10^{-11}\left( \pm 7.74 \times 10^{-12}\right)$ \\
\hline Terrestrial acidification & Species.yr & $2.17 \times 10^{-11}\left( \pm 2.97 \times 10^{-12}\right)$ \\
\hline Terrestrial eco-toxicity & Species.yr & $2.43 \times 10^{-11}\left( \pm 9.14 \times 10^{-12}\right)$ \\
\hline Urban land occupation & Species.yr & $1.11 \times 10^{-10}\left( \pm 1.45 \times 10^{-11}\right)$ \\
\hline \multicolumn{3}{|c|}{ Damage Assessment } \\
\hline Human health & DALY & $9.95 \times 10^{-7}\left( \pm 1.05 \times 10^{-7}\right)$ \\
\hline Ecosystem quality & Species.yr & $3.39 \times 10^{-9}\left( \pm 4.03 \times 10^{-10}\right)$ \\
\hline Resources & $\$$ & $1.53( \pm 0.16)$ \\
\hline \multicolumn{3}{|c|}{ Single Score } \\
\hline Total & mPt. & $44.9( \pm 4.39)$ \\
\hline
\end{tabular}

As for impact categories, Fig 2 shows the impact on the 17 categories. Climate change, fossil depletion, particulate matter formation, and human toxicity were the significant contributors to the damage. Major impact from processes was related to climate change human health $\left(5.4 \times 10^{-7} \mathrm{DALY}\right.$ equal to $\left.15.4 \mathrm{mPt}\right)$ (Table 1). The second highest impact is related to fossil depletion ( $\$ 1.44$ equal to $13.0 \mathrm{mPt})$, while the third highest impact is on particulate matter formation $\left(2.98 \times 10^{-7} \mathrm{DALY}\right.$ equal to $\left.8.9 \mathrm{mPt}\right)$ which is mainly related to emissions from electricity used in the plant. The figure shows that the emissions are the major contributor to the human toxicity and particulate matter formation, and shows the importance to improve treatment in the plant.

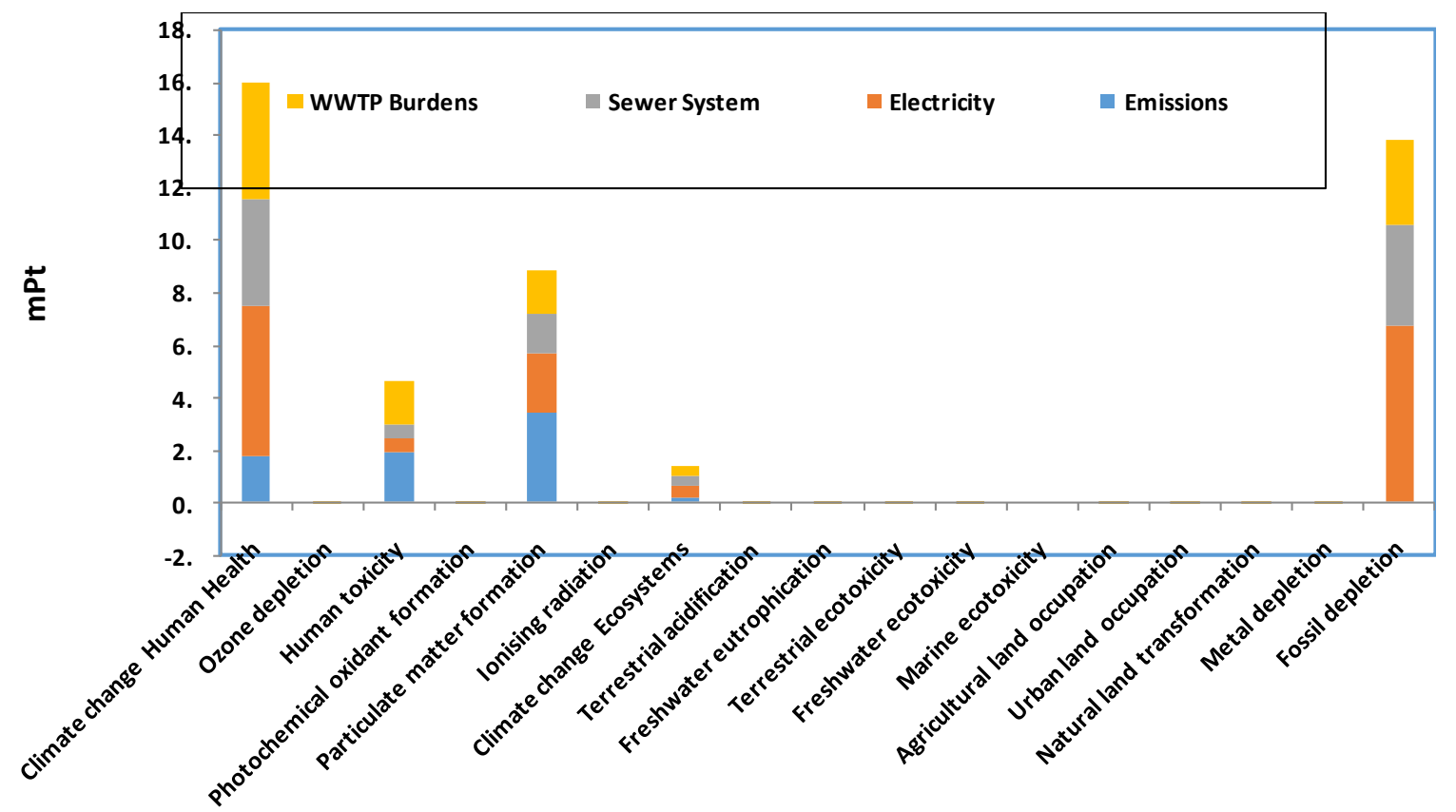

Fig 2 Weighted Impact Assessment Due to Treatment of One Cubic Meter of Raw Sewage at Alsamawah WWTP (Method: ReCiPe Endpoint (H) V1.05/World ReCiPe H/A/Weighting)

Climate change or global warming, particulate matter formation, and human toxicity are of the most common categories in wastewater treatment analysis. Corominas et al., showed that among 45 studies reviewed on wastewater treatment, 38 of them considered global warming potential but none of them analyzed the particulate matter formation or human toxicity potentials [34]. Employing weighting of ReCipe Method shows the need to pay attention to these categories as well. Fig 2 shows that particulate matter formation and carcinogens cause human toxicity both have an impact that cannot be neglected.

Figures 1 and 2 show significant contribution from construction materials of wastewater treatment plant. These results are not consistent with the studies that neglected the environmental impacts related to construction of the facilities [27, 12,26]. The Figures show that the environmental impacts of the construction phase of wastewater treatment processes are not negligible. However, the size of the plant is highly affect the contribution of construction materials or construction phase. Impacts from construction materials in small plant (like 5 MGD or less) usually significant as showed by Hong et al. [28]. The Figure shows no contribution from 
chemicals since the plant used none. No sludge was taken from the plant since operations started so no impacts from transportation to farms as well.

The average annual cubic meter of wastewater treated by the plant is $20,000 \mathrm{~m}^{3}$. Using ReCipe method which supports the analysis of environmental burdens from the treatment processes in terms of the final damages to human health, eco-system, and resources, total annual damages can be calculated. The annual damage to human health was an average of 7.3 DALYs. This damage is relatively high when compare to plants with high flow rate (the plant receives only 5.2 MGD). This number of DALYs is relate only to the process of treatment and do not indicate the losses of human life due to spreading of pathogens. The annual species lost due to processes is 0.025 , and the annual surplus expenses needed to extract resources in the future is an average of $\$ 1.11 \times 10^{+7}$.

\section{Conclusions And Recommendation}

Like many other WWTPs in the country, the WWTP in Alsamawah, Iraq needs high efforts to overcome its inefficiencies. Although high energy and burdens for WWTP and sewer system were used, the plant was not able to reduce contaminants such as COD, TSS, oil and grease, or nutrients, and failed to comply with local regulations. Electricity and burdens from constructing WWTP and its sewer system turned out to be the main contributors to the performance of the treatment process in the WWTP. Analysis of treatment showed that most damages are related to climate change, depletion in resources, and human toxicity. In this case study (flow of 5.2 MGD), construction phase had significant contribution to environmental burdens.

Endpoint approach make it easier for decision makers for evaluation of treatment in a WWTP, and for the environmental activists to show the environmental concerns to the public. For this case study, and in terms of annual damages, if the plant continue the existing treatment method, they cause the city of Alsamawah 7.3 $( \pm 0.8)$ DALYs in human, $2.5 \times 10^{-2}\left( \pm 2.9 \times 10^{-3}\right)$ species loss, and $\$ 1.1 \times 10^{+7}\left( \pm 1.2 \times 10^{+6}\right)$ more expenses on future generations. Treatment of one cubic meter wastewater in Alsamawah WWTP cause an environmental burdens equal to $44.9 \mathrm{mPt}$. $( \pm 4.39)$.

It is recommended that the City of Alsamawah put more efforts to achieve efficient treatment in reducing the discharging pathogens and other pollutants. If such efficiency was achieved, it is recommended to use solids as a resource of energy to offset burdens related to treatment.

\section{Acknowledgement}

I would like to thank the administration in Alsamawah Wastewater Treatment Plant in Sewer District in Alsamawah, Iraq for providing data and plant's technical information. Also, I would like to acknowledge The Department of Civil Engineering at Southern Illinois University Edwardsville, U.S. for providing the LCA software and other needed academic support.

\section{References}

[1]. UNICEF. 2011. "Water in Iraq: Facts and Figures" International World Water Day. Available online at: http://iq.one.un.org/documents/155/UNICEF\%20media\%20advisory\%20and\%20facts.pdf (5/10/2016).

[2]. UNICEF. 2003. "Iraq Watching Briefs, Water and Environmental Sanitation." http://www.unicef.org/evaldatabase/files/Iraq_2003_Watching_Briefs.pdf (06/02/2016).

[3]. World Bank. 2006. "Iraq: Country Water Resources, Assistance Strategy: Addressing Major Threats to People's Livelihoods." Water, Environment, Social and Rural Development Department. Middle East and North Africa Region. Report No. 36297-IQ. Also Available online at: 〈http://siteresources.worldbank.org/INTWAT/Resources/Iraq.pdf> (06/02/2016).

[4]. Al-Rawi, S. M. 2005. Contribution of Man-Made Activities to the Pollution of the Tigris within Mosul Area/IRAQ. International journal of environmental research and public health, 2(2), 245-250.

[5]. Al-Obaidi, R. 2012. "Aeration Tank Behavior in the Activated Sludge Wastewater Treatment Plant Startup Conditions." AlMuthanna for Engineering. Sci., Vol (1), NO (1).

[6]. Al-Rawi, S.M. and Altayar, T.A. 1993. Evaluation of the role of biological treatment in removing various wastewater pollutants. $J$. Environmental Science and Health, A28 (3): 252-263.

[7]. Alsaqqar, A., Khudair, B., and Mekki, A. 2014. "Assessment Efficiency Evaluation of Al-Diwaniya Sewage Treatment Plant in Iraq." J. of Engineering, Vol. (20), No. (2), Feb. 2014.

[8]. Roeleveld P. J., A. Klapwijk, P. G. Eggels, W. H. Rulkens, and W. Van Starkenburg. 1997. Sustainability of Municipal Wastewater Treatment. Water Science Technology, vol. 35, No. 10, pp. 221-228, 1997.

[9]. Tillman, A.M., Svingby, M., and Lundstrom, H. 1998. "Life Cycle Assessment of Municipal Wastewater Systems." Inter. J. of LCA 3: $145-157$.

[10]. ISO. 2006. "ISO 14040: Environmental management: Life-cycle assessment: Principles and framework." International Organization for Standardization, Geneva, Switzerland. Available at http://www.iso.org.

[11]. Guinee, J.B., Heijungs, R., Huppes, G., Zamagni, A., Masoni, P. 2011. Life cycle assessment: past, present, and future. Environmental Science and Technology 45 (1), 90e96.

[12]. Hospido, A., Feijoo, G., Gestagua, S., Moreira, T., and Fernandez-Couto, M. 2004. "Environmental Performance of A Municipal Wastewater Treatment Plant.” International Journal of LCA, 9(4), 261-271.

[13]. Ortiz, M., Raluy, R., Serra, L., and Uche, J. 2007. "Life Cycle Assessment of Water Treatment Technologies: Wastewater and Water Reuse in a Small Town." Desalination, 204(1-3), 121-131.

[14]. Machado, A., Urbano, L., Brito, A., Janknecht, P., Salas, J., and Nogueira, R. 2007. "Life Cycle Assessment of Wastewater Treatment Options for Small and decentralized Communities.” Water Science \& Technology, 56(3), 15-22. 
[15]. Munoz, I., Peral, J., Ayllon, J., Malato, S., Martin, M., Perrot, J., Vincent, M. and Domenech, X. 2007. "Life-cycle Assessment of a Coupled Advanced Oxidation-Biological Process for Wastewater Treatment: Comparison with Granular Activated Carbon Adsorption." Environmental Engineering Science, 24(5), 638-651.

[16]. Pasqualino, J., Meneses, M., Abella, M., and Castells, F. 2009. "LCA as a Decision Support Tool for the Environmental Improvement of the Operation of a Municipal Wastewater Treatment Plant.” Environ. Sci. Tech., 43(9), 3300-3307.

[17]. Bravo, L., and Ferrer, I. 2011. "Life Cycle Assessment of an Intensive Sewage Treatment Plant in Barcelona (Spain) with Focus on Energy Aspects." Water Science and Technology, 64(2), 440-447.

[18]. Bishop, P. 2000. "Pollution Prevention: Fundamentals and Practice." McGraw-Hill Series in Water Res. Environ. Eng., University of Cincinnati, ISBN: 0-07-366147-3.

[19]. Zamagni A, Masoni P, Buttol P, Raggi A, Buonamici R. 2012. Finding Life Cycle Assessment Research Direction with the Aid of Meta-Analysis. J of Ind Ecol 16: S39-S52. doi: 10.1111/j.1530-9290.2012.00467.X

[20]. Goedkoop M.J., Heijungs R, Huijbregts M., De Schryver A.;Struijs J., Van Zelm R,. 2013. "ReCiPe 2008: A life cycle impact assessment method which comprises harmonised category indicators at the midpoint and the endpoint level; First edition Report I: Characterisation; 6 January 2009, http://www.lcia-recipe.net

[21]. Bare JC, Hofstetter P, Pennington DW, Udo de Haes HA. 2000. Midpoints versus Endpoints: The Sacrifices and Benefits. Inter J of LCA 5(6): 319-326.

[22]. PRe Consultants (Mark Goedkoop, Michiel Oele, An de Schryver, Sipke Durksz, and Douwe de Roest). 2010. "SimaPro 7 Introduction into LCA.” Available in SimaPro 7.

[23]. Jolliet, O., Margni, M., Charles, R., Humbert, S., Payet, J., Rebitzer, G., and Rosenbaum, R. 2003. "IMPACT 2002+: A New Life Cycle Impact Assessment Methodology". Inter. J. of LCA, 8(6), 324-330.

[24]. Humbert, S., Schryver, A. D., Bengoa, X., Margni, M., Jolliet O. 2014. "IMPACT 2002+: User Guide; Draft for Version Q2.21".

[25]. Lundin, M., Bengtsson, M., Molander, S. 2000. "Life Cycle Assessment of Wastewater Systems: Influence of System Boundaries and Scale on Calculated Environmental Loads." Environ. Sci. Technol., 34(1), 180-186. DOI: 10.1021/es990003f.

[26]. Suh, Y., and Rousseaux, P. 2002. "An LCA of Alternative Wastewater Sludge Treatment Scenarios." Resour. Conserv. Recy., 35(3), 191-200.

[27]. Murray, A., Horvath, A., and Nelson, K. 2008. "Hybrid Life Cycle Environment and Cost Inventory of Sewage Sludge Treatment and End-Use Scenarios: A Case Study from China." Environ. Sci. Tech., 42(9), 3163-3169.

[28]. Hong, J., Hong, J., Otaki, M., and Jolliet, O. 2009. "Environmental and Economic Life Cycle Assessment for Sewage Sludge Treatment Processes in Japan.” Waste Manage., 29(2), 696-703.

[29]. U.S. Environmental Protection Agency (USEPA), 2015. "Energy Use in Wastewater Treatment Plants: Data Trends." http://www.energystar.gov/sites/default/files/tools/DataTrends_Wastewater_20150129.pdf (3/2/2016).

[30]. Warren, K. J. 2010. "Pennsylvania's Regulation of Total Dissolved Solids." The Legal Intelligencer, Philadelphia, 2010, Vol 242, No. 54.

[31]. Churchill, P. and Elmer, D. 1999. "Hydrogen Sulfide Odor Control in Wastewater Collection Systems." Newea Journal, Vol. 33, No. 1.

[32]. National Health and Welfare Canada (NHWC). 1978. "Guidelines for Canadian Drinking-Water Quality." Supporting Documentation. Ottawa, 1978

[33]. U.S. Environmental Protection Agency (USEPA). 1988. “Ambient Water Quality Criteria for Chloride-1988.” EPA 440/5-88-001.

[34]. Corominas L, Foley J, Guest J, Hospido A, Larsen H, Morera S, Shaw A. 2013. Life Cycle Assessment Applied to Wastewater Treatment: State of the Art. Water Res 47: 5480-5492. doi: 10.1016/j.watres.2013.06.049 